\title{
Intermediate filament protein nestin is expressed in developing meninges
}

\author{
Yay $\mathrm{A}^{1}$ Ozdamar $\mathrm{S}^{1}$ Canoz $\mathrm{O}^{2}$, Baran $\mathrm{M}^{2}$ Tucer $\mathrm{B}^{3}$, Sonmez $\mathrm{MF}^{1}$ \\ Department of Histology and Embryology, School of Medicine, University of Erciyes, Kayseri, Turkey. \\ arzu.yay38@gmail.com
}

\begin{abstract}
Background: Nestin is a type VI intermediate filament protein known as a marker for progenitor cells that can be mostly found in tissues during the embryonic and fetal periods. In our study, we aimed to determine the expression of nestin in meninges covering the brain tissue at different developmental stages and in the new born.

Methods: In this study 10 human fetuses in different development stages between developmental weeks 9-34 and a newborn brain tissue were used. Fetuses in paraffin section were stained with H+E and nestin immunohistochemical staining protocol was performed.

Results: In this study, in the human meninges intense nestin expression was detected as early as in the 9th week of development. Intensity of this expression gradually decreased in later stages of development and nestin expression still persisted in a small population of newborn meningeal cells.

Conclusion: In the present study, nestin positive cells gradually diminished in the developing and maturing meninges during the fetal period. This probably depends on initiation of a decrease in nestin expression and replacement with other tissue-specific intermediate filaments while the differentiation process continues. These differences can make significant contributions to the investigation and diagnosis of various pathological disorders (Tab. 1, Fig. 3, Ref. 36). Text in PDF www.elis.sk.

Key words: nestin, meninges, immunohistochemistry.
\end{abstract}

The human meninges perform many functions in the developing and adult human central nervous system (CNS) and are composed of a number of different cell types. The meninges exert structural and functional heterogeneity even though grouped together. They appear early during human development and originate from paraxial mesenchyme. Meningeal mesenchyme derived from neural crest cells initially forms a cellular network between the brain and skin that is without discriminating features $(1,2)$. The first meninges appeared as two mesenchymal condensations in the head area of early human embryos. The two condensations differentiate into parts of the head skeleton, as well as into the dura mater and the underlying leptomeninges (arachnoid and pia mater), might have proliferation potential during development such as stem cells, during the development (3). These two mesenchymal condensations in the development of the meninges subsequently differentiated into two different tissue components: connective tissue internally, dense in the dura mater and loose in the leptomeninges, and the epithelial component on the surface of the meninges. The epithelial components appeared as a result of

${ }^{1}$ Department of Histology and Embryology, School of Medicine, University of Erciyes, Kayseri, Turkey, ${ }^{2}$ Department of Pathology, School of Medicine, University of Erciyes, Kayseri, Turkey, and ${ }^{3}$ Department of Neurosurgery, School of Medicine, University of Erciyes, Kayseri, Turkey

Address for correspondence: A. YAY, PhD, Department of Histology and Embryology, School of Medicine, University of Erciyes, Kayseri, Turkey, 38090

Phone: +352.2076666 , Fax: +352.4377627 mesenchymal to epithelial transformation (4). This process in the cells of mesenchymal tissue was characterized by the replacement of mesenchymal proteins with the epithelial proteins and appearance of the typical basement membrane underlying epithelium (5).

The meninges control some aspects of cortical neurogenesis and neuronal migration $(6,7)$. Meninges in the brain and spinal cord may also directly harbor stem cells under basal conditions (8) and in response to insults, such as stroke and spinal cord injury $(9,10)$. Thus, the meninges regulate the development of the brain and may also harbor stem cells in adult brain.

Nestin is an intermediate filament protein expressed during the developmental stages in a variety of embryonic and fetal tissues (11). The functional significance of nestin expression has not been fully elucidated (12). Nestin was first identified in mitotically active central and peripheral nervous system stem/progenitor cells that give rise to both neurons and glia during early neurogenesis $(13,14)$. It is also detected in some adult stem/progenitor cells; such as newborn vascular endothelial cells (15-17), striated muscle precursor cell (18), hair follicle precursor cell (19), islet precursor cell (20) and liver oval cell (21). Nestin may represent the proliferation, migration and multi-differentiated characteristics of multi-lineage progenitor cells (11). Due to its characteristic expression pattern, nestin is generally considered as a marker of stem cells or progenitor cells (22).

A possible role was ascribed to nestin in growing CNS, especially in neuroepithelial stem cells and gliomas in previous studies on human tissues and in experimental animals $(23,24)$. The aim 
of this study was to analyze nestin expression in embryonic, fetal and postnatal human meninges.

\section{Methods}

\section{Tissues and HE staining}

In the current study, a total of 10 human concepti between developmental weeks 9 and newborn were collected after spontaneous abortions from Department of Pathology, University of Erciyes, Faculty of Medicine (Tab.1). This study was approved by the Institutional Research Ethics Committee and adhered to Declaration of Helsinki guidelines (25).

The head areas of embryo and fetus were fixed in $10 \%$ formaldehyde for 24 hours followed by dehydration through a graded ethanol series. These samples were made transparent in xylol and embedded in paraffin wax. Sections in $5 \mu \mathrm{m}$ thickness obtained from samples were transferred to slides covered with poly-L-lysine to prevent detachment. Every section was stained with hematoxylin-eosin to determine the morphological appearance of each part of the meninges in this section.

\section{Nestin immunohistochemistry}

Sections of $5 \mu \mathrm{m}$ thick were obtained with microtom and were put on poly-L-lysine slides, and immunohistochemical procedures were applied after completion of the deparaffinization and rehydration stages. Immunohistochemistry was performed by using the avidin-biotin-peroxidase method and applied using a streptavidin-biotin kit. Briefly, each tissue section was deparaffinized, rehydrated and then incubated with $3 \%$ fresh hydrogen peroxide $\left(\mathrm{H}_{2} \mathrm{O}_{2}\right)$ in methanol for $10 \mathrm{~min}$. After rinsing with phosp-
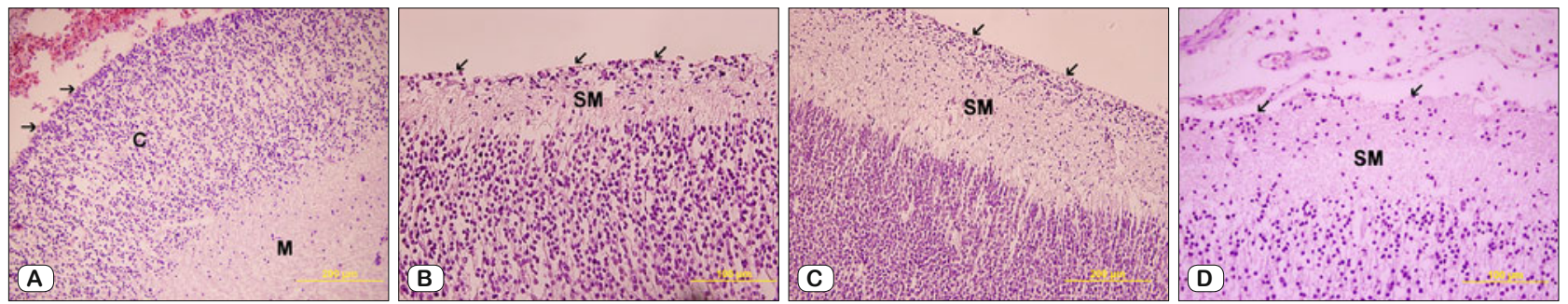

Fig. 1. (A) The newly shaped meninges in the head area of a 9-week human embryo (arrow). C - Cortex, M - Medulla (H\&E, x20). (B) At week 19 of human development, light microscopic appearance of mesenchymal layer that will be shaped on the surface of the molecular layer (arrow). SM - Stratum moleculare (H\&E, x40). (C) The light microscopic appearance of fetal brain tissue at week 22. SM - Stratum moleculare (H\&E, x20). (D) At developmental week 33, the meningeal cells surrounding the outer layer of brain tissue (arrow). SM-Stratum moleculare (H\&E, x40).
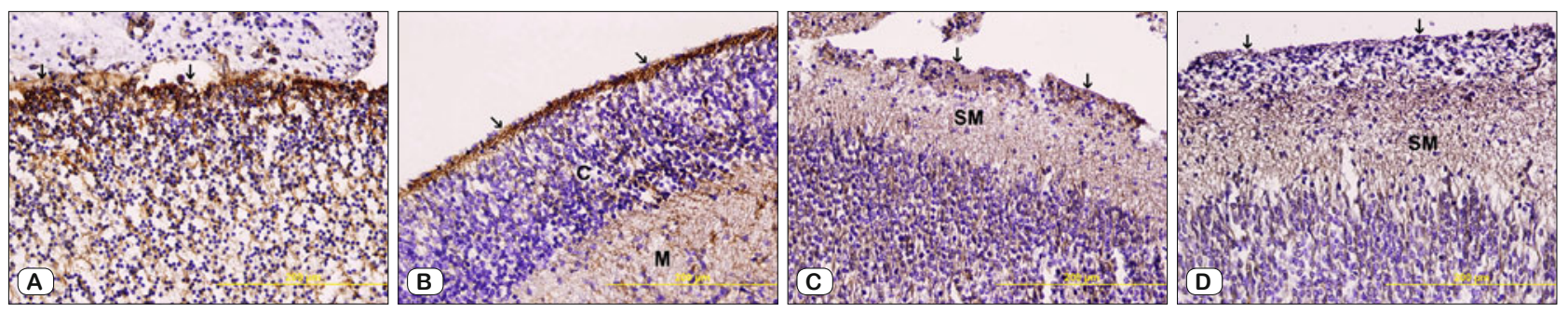

Fig. 2. (A) Nestin expression of the meninges at week 9 of human development (arrow). (B) Nestin expression in sections of human meninges at week 14 (arrow). C - Cortex, M - Medulla (C) Sections of human meninges and nestin expression of meningeal cells at week 19 (arrow). SM Stratum moleculare (D) The decrease in the expression of nestin at week 22 (arrow). SM - Stratum moleculare (Immunostaining of nestin, x40).
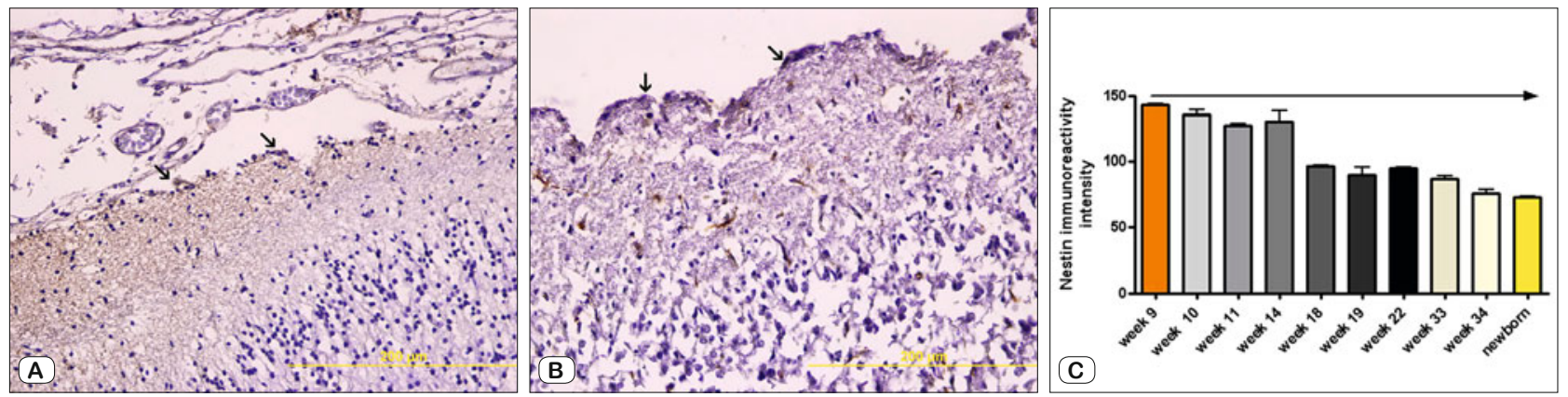

Fig. 3. (A) At more later stages of fetal development, meningeal cells at week 33 of the development of human meninges (arrow). (B) Nestin expression in the meninges covering newborn human brain tissue (arrow). (Immunostaining of nestin, $x$ 40). (C) During further development, immunoreactivity intensity of nestin increased in the cells of developing meninges. At later fetal developmental stages, immunoreactivity intensity of nestin decreased in all parts of developing meninges. 


\section{8-722}

hate-buffered saline (PBS), antigen retrieval was carried out by microwave treatment in $0.01 \mathrm{M}$ sodium citrate buffer $(\mathrm{pH}$ 6.0) at $100{ }^{\circ} \mathrm{C}$ for $15 \mathrm{~min}$. Next, non-specific binding was blocked with normal goat serum for $15 \mathrm{~min}$ at room temperature, followed by incubation with monoclonal Mouse anti-human nestin antibody ( $\mathrm{Rb}$ X nestin, AB 5922, Millipore, final dilution 1:200) overnight at $4{ }^{\circ} \mathrm{C}$. After rinsing with PBS, the slides were incubated for 10 min at room temperature with biotin-conjugated secondary antibodies, followed by incubation with streptavidin-conjugated peroxidase working solution for $10 \mathrm{~min}$. Subsequently, sections were stained for 10 min with 3,3'-diaminobenzidine tetrahydrochloride (DAB), counterstained with Mayer's hematoxylin, dehydrated and mounted. Negative controls were prepared by substituting PBS for primary antibody. All applications were performed at room temperature in a moist ambient to prevent samples from drying. The prepared samples were inspected by Olympus BX51 microscopy (Olympus, Tokyo, Japan).

\section{Quantitative immunohistochemistry}

In total, 10 samples were stained with nestin. Different reference areas (per visual fields) from fetuses were randomly defined and then analysis was performed on sections. The programs of Image $\mathbf{J}$ software and Graph Pad Prism were used to evaluate immune-reactivity intensity of nestin.

\section{Results}

Mesenchymal cell intensity covered 9 weeks, early embryonic process, brain tissue and the area that meninges will be developing from were evident. At this stage stratums have not been distinguished in the brain cortex (Fig. 1a). During early human development, layer distinguished in cortex is stratum moleculare, the nearest to cortex surface. Developed meninges were placed on this layer and covered all brain surface (Fig. 1b, c). Towards the end of the fetal life, brain tissue was similar to adult brain tissue with its neurons and other stratums. The molecular layer, the nearest to stratum moleculare surface of brain cortex was quite evident and had similar features to adult meninges (Fig. 1d).

Nestin expressed in progenitor cells during embryonic and fetal process was found in human meninges as early as in the 9th week of development (Fig. 2a). Its expression firstly increased during embryonic and early fetal periods. The gradually decreasing expression seen in mezenchymal condensation depends on fetal developing in area of the developing meninges (Fig. 2b, c, d). In later stages of fetal development, nestin positive cell populations were detected to be decreased in this area (Fig. 3a). Even during the postpartum period, nestin expression was negative in the most of the area of meninges, while weak expression of nestin was observed in some meningeal cells (Fig. $3 b)$. Nestin expression in meninges of fetuses in different stages of development gradually decreased in progression of differentation. When this groups were compared in terms of intensity of nestin expression, gradual decrease of nestin expression was statistically significant depending on the progression of fetal development (Fig. 3c).

\section{Discussion}

Recently, the intermediate filament proteins were shown to have important roles in cell division, proliferation and migration through participating in cytoplasmic transport. The change mechanism of the intracellular organisations is still not fully understood in various situations such as mitosis, differentiation and different pathological conditions of dynamic structure of intermediate filament proteins $(26,27)$. The word nestin is an acronym of neuroepithelial stem cell protein (28) and it is a type VI intermediate filament protein forming bundles in neuroepithelial stem/progenitor cells in the growing central nervous system of rat embryos and in humans $(20,30)$. Nestin was expressed mostly in the progenitor cells of developing and innovating tissues in early periods of neural development and in CNS stem cells. Nestin was firstly identified by immunohistochemistry (13). Nestin expression in adult tissues was attributed to stem cell and progenitor cell populations. It was postulated that these progenitor cells are reactivated and proliferate and migrate in response to injury during tissue regeneration (30). The studies on human tissues and experimental animals revealed that nestin was highly expressed in neuroepithelial stem cells in CNS development and in gliomas $(31,32)$. Recently, nestin was shown to be expressed in progenitor cells of developing human spinal ganglia (33) and optic nerve (34). Nestin was detected in neuronal precursor cells, developing skeletal and cardiac musle cells, mesonephric mesenchyme, pancreatic progenitor cells and vascular endothelium, among others (30). Nestin expression in those cells subsequently decreased at later developmental stages and finally disappeared in terminally differentiated and mature cells $(33,34)$. Nestin expression was thought to be transient in these progenitor cells and differentiation in specialized cells types resulted in down-regulation of nestin and expression of other cells type-specific intermediate filaments, like neurofilaments in neurons (35).

Nestin expression in rat leptomeningeal cells was found at different developmental stages, however, gradually diminished in later fetal development and in the newborn (23). Nestin was temporarily expressed in multipotent neuroepithelial stem cells during embryonic development (36). Similar to these findings, in the present study, we detected nestin expression as early as in the 9th developmental week in human meninges and then it gra-

Tab. 1. The intrauterine development weeks and number of human embryos.

\begin{tabular}{ccc}
\hline Case & Weeks (Age) & Number \\
\hline 1 & 9 & 1 \\
2 & 10 & 1 \\
3 & 11 & 1 \\
4 & 14 & 1 \\
5 & 18 & 1 \\
6 & 19 & 1 \\
7 & 22 & 1 \\
8 & 33 & 1 \\
9 & 34 & 1 \\
10 & Newborn & 1 \\
\hline
\end{tabular}


dually decreased in later fetal development and after birth. In our study, according to the pattern of nestin expression in developing meninges, nestin may be demonstrated as a possible marker of immature cells during early development and later development stages. The cells expressing nestin represented immature cells which subsequently diminished during development of meninges, however still remained in a small population of normal meningeal cells after birth.

The identity of intermediate filament proteins in human meninges is incompletely understood. Their role is not established in pathologies, such as meningiomas, meningeal carcinomatosis or meningitis. In conclusion, nestin expression in immature meningeal cells of ectodermal origin was present both, during development process and after the birth. Nestin positive cells during maturation and development of meninges subsequently diminished, however, still remained in a small meningeal cells population in newborn brain tissue. This probably depends on decreased nestin expression and replacement with other tissuespesific intermediate filament proteins with advancing development. We speculate that these differences may have a significant contribution in the areas of investigation and diagnosis of various pathological disorders.

\section{References}

1. Chen J, Boyle S, Zhao M, Su W, Takahashi K, Davis L, DeCaestecker M, Takahashi T, Breyer DM, Hao C. Differential expression of the intermediate filament protein nestin during renal development and its localization in adult podocytes. J Am Soc Nephrol 2006; 17 (5): 1283-1291.

2. Gagan JR, Tholpady SS, Ogle RC. Cellular dynamics and tissue interactions of the dura mater during head development. Birth Defects Res C Embryo Today 2007; 81 (4): 297-304.

3. Angelov DN, Vasilev VA. Morphogenesis of rat cranial meninges: a light and electron-microscopic study. Cell Tissue Res 1989; 257 (1): 207-216.

4. O'Rahilly R, Müller F. The meninges in human development. J Neuropathol Exp Neurol 1986; 45 (5): 588-608.

5. Herric SE, Mutsaers SE. Mesothelial progenitor cells and their potential in tissue engineering. Int J Biochen Cell Biol 2004; 36 (4): 621-642.

6. Lopez-Bendito G, Snachez-Alcaniz JA, Pla R, Borrell V, Pico E, Valdeolmillos M, Marin O. Chemokine signaling controls intracortical migration and final distribution of GABAergic interneurons. J Neurosci 2008; 28 (7): 1613-1624.

7. Siegenthaler JA, Ashique AM, Zarbalis K, Patterson KP, Hecht JH, Kane MA, Folias AE, Choe Y, May SR, Kume T, Napoli JL, Peterson AS, Pleasure SJ. Retinoic acid from the meninges regulates cortical neuron generation. Cell 2009; 139 (3): 597-609.

8. Bifari F, Decimo I, Chiamulera C, Bersan E, Malpeli G, Johansson J, Lisi V, Bonetti B, Fumagalli G, Pizzolo G, Krampera M. Novel stem/progenitor cells with neuronal differentiation potential reside in the leptomeningeal niche. J Cell Mol Met 2009; 13 (9B): 3195-3208.

9. Decimo I, Bifari F, Rodriguez FJ, Malpeli G, Dolci S, Lavarini V, Pretto S, Vasquez S, Sciancalepore M, Montalbano A, Berton V, Krampera M, Fumagalli G. Nestin- and doublecortin-positive cells reside in adult spinal cord meninges and participate in injury-induced parenchymal reaction. Stem Cells 2011; 29 (12): 2062-2076.
10. Nakagomi T, Molnar Z, Nakano-Doi A, Taguchi A, Saino O, Kubo S, Clausen M, Yoshikawa H, Nakagomi N, Matsuyama T. Ischemiainduced neural stem/ progenitor cells in the pia mater following cortical infarction. Stem Cells Dev 2012; 20 (12): 2350-2354.

11. Yang XH, Wu OL, Yu XB, Yu CX, Ma BF, Zang XM, Li SN, Lahn BT, Xiang AP. Nestin expression in different tumours and its relevance to malignant grade. J Clin Pathol 2008; 61 (4): 467-473.

12. Michalczyk K, Ziman M. Nestin structure and predicted function in cellular cytoskeletal organisation. Histol Histopathol 2005; 20 (2): 665671.

13. Hockfield S, McKay RD. Identification of major cell classes in the developing mammalian nervous system. J Neurosci 1985; 5 (12): 3310-3328.

14. Wiese C, Rolletschek A, Kania G, Blyszczuk P, Tarasov KV, Tarasova Y, Wersto RP, Boheler KR, Wobus AM. Nestin expression: A property of multi-lineage progenitor cells? Cell Moll Life Sc 2004; 61 (19-20): $2510-2522$.

15. Shimizu T, Sugawara K, Tosaka M, Imai H, Hoya K, Takeuchi T, Sasaki T, Saito N. Nestin expression in vascular malformations: a novel marker for proliferate endothelium. Neurol Med Chir 2006; 46 (3): $111-117$.

16. Mokrý J, Cízková D, Filip S, Ehrmann J, Osterreicher J, Kolár Z, English D. Nestin expression by newly formed human blood vessels. Stem Cells Dev 2004; 13 (6): 658-664.

17. Amoh Y, Yang M, Li L, Reynoso J, Bouvet M, Moossa AR, Katsuoka K, Hoffman RM. Nestin-linked green fluorescent protein transgenic nude mouse for imaging human tumor angiogenesis. Cancer Res 2005; 65 (12): 5352-5357.

18. Sejersen T, Lendahl U. Transient expression of the intermediate of the intermediate filament nestin during skeletal muscle development. J Cell Sci 1993; 106: 1291-1300.

19. Li L, Mignone J, Yang M, Matic M, Penman S, Enikolopov G, Hoffman RM. Nestin expression in hair follicle sheath progenitor cells. Proc Natl Acad Sci USA 2003; 100 (7): 9958-9961.

20. Maria-Engler SS, Corrêa-Giannella ML, Labriola L, Krogh K, Colin C, Lojudice FH, Aita CA, de Oliveira EM, Corrêa TC, da Silva IC, Genzini T, de Miranda MP, Noronha IL, Vilela L, Coimbra CN, Mortara RA, Guia MM, Eliaschewitz FG, Sogayar MC. Co-locolization of nestin and insulin and expression of islet cell markers in long-term human pancreatic nestin-positive cell cultures. J Endocrinol 2004; 183 (3): 455-467.

21. Gleiberman AS, Encinas JM, Mignone JL, Mignone JL, Michurina T, Rosenfeld MG, Enikolopov G. Expression of nestin green fluorescent protein transgene marks oval cells in the adult liver. Dev Dyn 2005; 234 (2): 413-421.

22. Thiery JP. Epithelial-mesenchymal transitions in development and pathologies. Curr Opin Cell Biol 2003; 15 (6): 740-746.

23. Petricevic J, Forempoher G, Ostojic L, Mardesic-Brakus S, Andjelinovic S, Vukojevic K, Saraga-Babic M. Expression of nestin, mesothelin and epithelial membrane antigen (EMA) in developing and adult human meninges and meningiomas. Acta Histochem 2011; 113 (7): 703-711.

24. Dahlstrand J, Collins VP, Lendahl U. Expression of the class VI intermediate filament nestin in human central nervous system tumours. Cancer Res 1992; 52 (19): 5334-5341.

25. Williams JR. The declaration of Helsinki and public health. Bull World Health Org 2008; 86 (8): 650-652. 


\section{$718-722$}

26. Vaittinen S, Lukka R, Sahlgren C, Rontenen J, Hurme T, Lendahl U, Eriksson J E, Kalimo H. Specific and innervation-regulated expression of the intermediate filament protein nestin at neuromuscular and myotendinous junctions in skeletal muscle. Am J Pathol 1999; 154 (2): 591-600.

27. Inogaki M, Matsuoka Y, Tsujimura K, Ando S, Tokuı T, Takahoshı T, Inagaki N. Dynamic property of intermediate filaments: regulation of phosphorylation. Bio Essays 1996; 18 (6): 481-487.

28. Geisler N, Hatzfeld M, Weber K. Phosphorylation in vitro of vimentin by protein kinases $\mathrm{A}$ and $\mathrm{C}$ is restricted to the head domain. Identification of the hosphoserine sites and their influence on filament formation. Eur $\mathrm{J}$ Biochem 1989; 183 (2): 441-447.

29. Chinnaiyan P, Wang M, Rojiani AM, Tofilon PJ, Chakravarti A, Ang KK, Zhang HZ, Hammond E, Curran WJr, Mehta MP. The prognostic value of nestin expression in newly diagnosed glioblastoma report from the Radiation Therapy Oncology Group. Radiat Oncol 2008; 3: $32-39$.

30. Wagner N, Wagner KD, Xing Y, Scholz H, Schedl A. The major podocyte protein nephrin is transcriptionally activated by the Wilms' Tumour suppressor WT1. J Am Soc Nephron 2004; 15 (12): 3044-3051.

31. Morky J, Nemecek S. Angiogenesis of extra- and intra-embriyonic blood vessel is associated with expression of nestin in endothelial cells. Folia Biologica 1998; 44 (5): 155-161.
32. Barbareschi M, Pecciarini L, Cengi MG, Macri E, Riyyo A, Viale G, Daglioni C. p63, a p53 homologue, is a selective nuclear marker of myoepithelial cells of the human breast. Am J Surg Pathol 2000; 25 (8): 1054-1060.

33. Bozanic D, Bocina I, Saraga-Babic M. Skeletal proteins and growth factor receptors during development of the human eye. Anat Embryol (Berl) 2006; 211 (5): 367-377.

34. Vukojevic K, Skobic H, Saraga-Babic M. Proliferation and differentiation of glial and neuronal progenitors in the development of human spinal ganglia. Differentiation 2009; 78 (2-3): 91-98.

35. Cattazsen E, McKay R. Proliferation and differentiation of neuronal stem cells regulated by nerve growth factor. Nature 1990; 347 (6295): $762-765$.

36. Frisen J, Johansson CB, Torok C, Risling M, Lendahl U. Rapid, widespread and longlasting induction of nestin contributes to the generation of glial scar tissue after central nervous system injury. J Cell Biol 1995; 131 (2): 455-464.

Received April 26, 2013. Accepted March 15, 2014. 